\title{
Stability of infliximab solutions in different temperature and dilution conditions
}

N. TOKHADZE ${ }^{(1)}$, P. CHENNELL ${ }^{(1)^{*}}$, Y. LE BASLE ${ }^{(2)}$, V. SAUTOU $^{(1)}$

(1) UNIVERSITE CLERMONT AUVERGNE, CHU CLERMONT FERRAND, CNRS, SIGMA CLERMONT, ICCF, F63000 CLERMONT-FERRAND, FRANCE

(2) CHU CLERMONT-FERRAND, POLE PHARMACIE, F-63000 CLERMONT-FERRAND, FRANCE

* : corresponding author: pchennell@chu-clermontferrand.fr

DOI : 10.1016/j.jpba.2017.12.012

\section{Key words}

Infliximab; monoclonal antibody; Chemistry Techniques, Analytical; stability; dilution; temperature;

\section{Highlights}

- Storage at $25^{\circ} \mathrm{C}$ of diluted infliximab solutions did not increase aggregation levels

- Chemical instability of diluted infliximab was the main limiting factor at $25^{\circ} \mathrm{C}$

- A single freeze-thawing cycle of diluted infliximab caused significant instability

- Diluted Infliximab solutions were physicochemically stable 90 days at $5^{\circ} \mathrm{C}$

\begin{abstract}
Infliximab is a monoclonal antibody widely used for the treatment of inflammatory diseases. Over the past few years, many studies have assessed that monoclonal antibodies are prone to aggregation under stress conditions, such as temperature changes and agitation. The aim of this study was to assess stability of infliximab (Inflectra ${ }^{\circledR}$ ) solutions at different concentrations. These solutions were separately submitted to three temperature conditions that are likely to happen during the drug dispensing system: $-20^{\circ} \mathrm{C}, 5^{\circ} \mathrm{C}$ and $25^{\circ} \mathrm{C}$. To perform a complete characterization of infliximab physicochemical and structural stability a wide range of analytical techniques were employed including: visual inspection, subvisible particles counting (HIAC), dynamic light scattering (DLS), size exclusion chromatography (SEC), cation exchange chromatography (CEX), and analysis of primary, secondary and tertiary structure. When stored at $25^{\circ} \mathrm{C}$ and $5^{\circ} \mathrm{C}$ CEX was the main limiting factor, while SEC showed only some acceptable variation. After a single freeze-thawing cycle, the amount of subvisible particles was significantly increased. Some variations were also visible in CEX and hydrodynamic diameter was increased after thawing $10 \mathrm{mg} / \mathrm{mL}$ samples. In regard of these results, infliximab (Inflectra ${ }^{\circledR}$ ) solutions should not be used after a single freeze-thawing cycle between reconstitution and administration to the patient. The results showed a stability at $5^{\circ} \mathrm{C}$ of up to
\end{abstract}


14 days for $10 \mathrm{mg} / \mathrm{mL}$ solutions and 90 days for 0.4 and $2 \mathrm{mg} / \mathrm{mL}$ solutions, whilst samples stored at $25^{\circ} \mathrm{C}$ were stable only 7 days in original glass vials and 30 days when diluted.

\section{Introduction}

For several years now, treatments based on biological molecules have become ever more established as key therapeutic approaches. Infliximab is an $\lg G 1$ monoclonal antibody (mAb) that binds and inhibits transmembrane and soluble forms of Tumor Necrosis Factor alpha (TNF- $\alpha$ ). It is widely used in rheumatology for the treatment of rheumatoid arthritis in association with methotrexate, spondylitis ankylosing and psoriatic arthritis, and in gastroenterology for Crohn's Disease and ulcerative colitis and in dermatology for psoriasis. In 2013, infliximab CT-P23 became the first biosimilar monoclonal antibody approved by the EMA [1] and by the FDA in 2016 [2].

In a stability study one of the keys is to quantify the active substance and highlight any type of degradation that could alter the integrity of the studied molecule, and analytical techniques therefore play an essential role in this kind of studies. Yet, the stability of monoclonal antibodies (mAbs) is rather complex to assess due to the multiples degradation pathways. Infliximab, like other mAbs and biopharmaceutical drugs, is susceptible to many factors that can affect its stability in solution, such as temperature [3,4], pH, oxidation [5] and agitation [6]. Degradation of mAbs can be physical or chemical more or less related to structural modifications. Even if the complete mechanism has not been fully described yet, monoclonal antibodies are also well known for their tendency to form aggregates under stress conditions $[3,7]$. Aggregation of mAbs occurs at different level and no lone analysis is able to completely evaluate the whole phenomenon. Different analytical techniques bring specific information about nanoparticles, subvisible particles or aggregates molecular weight for example. All these techniques supplement one another and should be associated in order to increase the level of evidence, and a recent European consensus recommends the use of several analytical techniques to assess their physicochemical stability [8]. Pharmaceutical industries have enhanced the formulation of their biological drugs to slow down quantitative and qualitative modifications and thus extend their stability, following ICH guidelines [9-11]. Forced degradation studies also give information upon degradation mechanisms but are not always representative of what happens in real use conditions [12]. There is a lack of data on the long term storage of the Mabs and such studies are difficult to perform due to the high cost of this kind of drugs, thus depriving healthcare practitioners of critical information about mAbs stability in clinical use conditions.

Stability of reconstituted and diluted infliximab solutions is set up to $24 \mathrm{~h}$ for both biosimilars (according to summary of product characteristics of both REMSIMA ${ }^{\circledast}[3]$ and INFLECTRA ${ }^{\circledR}[4]$ ), limited by a hypothetically short microbiological stability. But when prepared in controlled atmosphere area 
microbiological stability is less of an issue, and overall stability depends on the limits of physicochemical stability.

The aim of this study was to evaluate the physicochemical stability of a biosimilar mAb (infliximab INFLECTRA $^{\circledast}$ ) for a wide concentration range at different storage temperatures, such as those possibly encountered in clinical situations for up to 90 days, using complementary analytical assays in order to understand the limits of mAb conservation in clinical settings.

\section{Materials and methods}

\subsection{Materials and reagents}

Inflectra ${ }^{\circledR}$ powder for solution for infusion (batch 2485036, expire on 09/30/2020) was provided for free of charge by Pfizer France SAS (Meudon, France). Sterile water for injection (Ecoflac ${ }^{\circledR}$ ) was purchased from B Braun Medical (SAS, Boulogne Billancourt Cedex, France) and sodium chloride 0.9\% infusion bags were purchased from Fresenius Kabi (Louviers, France). Sodium sulfate $\left(\mathrm{Na}_{2} \mathrm{SO}_{4}\right)$, disodium phosphate $\left(\mathrm{Na}_{2} \mathrm{HPO}_{4}\right)$, sodium azide $\left(\mathrm{NaN}_{3}\right)$, 4-Morpholinoethanesulfonic acid (MES), sodium chloride $(\mathrm{NaCl})$, Guanidine Hydrochloride $(\mathrm{GnHCl})$, Tris hydrochloride (Tris $\mathrm{HCl})$, ammonium carbonate, dithiothreitol (DTT), iodoacetic acid, acetylated trypsin, sodium hydroxide $(\mathrm{NaOH})$, hydrogen chloride $(\mathrm{HCl})$, acetonitrile and trifluoroacetic acid (TFA) were all purchased from Sigma-Aldrich (Saint Quentin Fallavier Cedex, France). All reagents were certified of HPLC grade.

\subsection{Preparation and conditioning}

$10 \mathrm{mg} / \mathrm{mL}$ infliximab solutions were sterilely prepared from Inflectra ${ }^{\circledR}$ powder for solution for infusion by adding water for injection to the medication vial, according to the manufacturer's instructions using a sterile metal needle (Blunt Fill Needle $18 \mathrm{G} \times 1 \frac{1}{2}{ }^{\prime \prime}$, Becton Dickinson, Spain), under the laminar air flow of an ISO 4.8 microbiological safety cabinet. Solutions were then diluted to 0.4 and $2 \mathrm{mg} / \mathrm{mL}$ into 0.9 $\mathrm{NaCl}$ infusion bags.

\subsection{Study design}

The prepared units were then stored in the dark for up to 30 days for the $10 \mathrm{mg} / \mathrm{mL}$ solutions and 90 days for the 0.4 and $2 \mathrm{mg} / \mathrm{mL}$ solutions at controlled refrigerated temperature (Whirlpool refrigerator) at $5^{\circ} \mathrm{C} \pm 2^{\circ} \mathrm{C}$ or in a climate chamber (BINDER GmbH, Tuttlingen, Germany) at $25^{\circ} \mathrm{C} \pm 2^{\circ} \mathrm{C}$ and $60 \%$ residual humidity, until analysis. The units dedicated to the freeze-thawing study were frozen at $-20^{\circ} \mathrm{C} \pm 2{ }^{\circ} \mathrm{C}$ for 60 hours. 
For the studies at $5^{\circ} \mathrm{C}$ and $25^{\circ} \mathrm{C}$, samples were analysed in triplicate at D0, D7, D14, D30 and D90, except for $10 \mathrm{mg} / \mathrm{mL}$ samples for which D90 was not performed. For the freeze-thawing study, samples were analysed at D0 and after 60 hours freezing after a complete thawing, assessed visually.

\subsection{Analyses}

Infliximab solutions were subjected to a series of analysis to investigate physical, chemical and structural stability. Total protein quantification was also performed. Before all analyses, the $10 \mathrm{mg} / \mathrm{mL}$ samples were diluted to $0.4 \mathrm{mg} / \mathrm{mL}$ of infliximab in sodium chloride solutions, except for subvisible particle determination for which the samples were analysed without dilution, and for peptide mapping analysis during which the samples were analysed at $2 \mathrm{mg} / \mathrm{mL}$. The $0.4 \mathrm{mg} / \mathrm{mL}$ and $2 \mathrm{mg} / \mathrm{mL}$ infliximab solution samples were analysed directly without dilution.

\subsubsection{Physical stability analysis}

\subsubsection{Visual inspection}

The solutions were visually inspected under a white light in front of a matt black panel and a nonglare white panel. Aspect and colour of the solutions were noted, and a screening for visible particles, haziness, or gas development was performed.

\subsubsection{Turbidimetry}

Turbidity was evaluated by measuring the absorbance of the infliximab solutions at $320 \mathrm{~nm}$ and $350 \mathrm{~nm}$ using a spectrophotometer UV/VIS/NIR Jasco V - 670 (Jasco France, Bouguenais, France) equipped with a single monochromator, a deuterium lamp (range 190 - 350nm) and a halogen lamp (range $330-2700 \mathrm{~nm}$ ). The results were analysed using the provided software (Spectra manager II)

An increase in the calculated aggregation index (Al) compared to the DO reference is indicative of an increase of samples turbidity.

Equation 1: Estimation of turbidity by calculation of Aggregation Index (Al). A corresponds to absorbance at specified wavelengths ( 280 and $350 \mathrm{~nm}$ )

$$
A I=\frac{A 350}{A 280-A 350} \times 100
$$

An Al value $<10$ was considered to be acceptable $[13,14]$ 


\subsubsection{Subvisible particles counting}

Subvisible particle counting was performed on a HIAC Royco 9703 (Hach Lange, Noisy le Grand, France) equipped with a HRLD 400 EC detector.

Four successive measurements were carried out on a volume of $5 \mathrm{~mL}$, and the first run was discarded. The results were expressed as the number of particles of size superior to $10 \mu \mathrm{m}$ and superior to $25 \mu \mathrm{m}$, per $\mathrm{mL}$ of solution. For the $10 \mathrm{mg} / \mathrm{mL}$ solutions, the triplicates from each condition were pooled together in order to have a sufficient volume to perform the analysis according to the European pharmacopeia monography (2.09.19)[15]. $10 \mathrm{mg} / \mathrm{mL}$ solutions were compared to the limits indicated in the European Pharmacopoeia 2.09.19 monography for small volume parenterals : <6000 particles /container (10 $\mu \mathrm{m}$ particles) and < 600 particles / container ( $25 \mu \mathrm{m}$ particles). Whereas 0.4 and $2 \mathrm{mg} / \mathrm{mL}$ solutions were compared to limits indicated in the European Pharmacopoeia 2.09 .19 monography for > $100 \mathrm{~mL}$ parenterals; $<25$ particles/mL equal to or greater than $10 \mu \mathrm{m}$ and $<3$ particles $/ \mathrm{mL}$ equal to or greater than $25 \mu \mathrm{m}$ [15]. Samples were considered to be conform if it didn't statistically increase when compared to $D_{0}$ values (Student test, $\alpha=0.05$ )

\subsubsection{Nanoparticles size determination}

Dynamic Light Scattering (DLS) allows the estimation of the size of protein aggregates between $0.3 \mathrm{~nm}$ and $10 \mu \mathrm{m}$. The particle size is obtained from the variation of intensity of light scattering due to Brownian motion of particles. Particle size was determined on $1 \mathrm{ml}$ of each sample in clear disposable polystyrene cells by dynamic light scattering measurements, using a Zetasizer Nano ZS (Malvern Instruments SARL, Orsay Cedex, France). Each sample was automatically screened 3 times. The obtained size distribution was presented by percentage of intensity and must conform to reference $\left(D_{0}\right)$ profiles. $A$ variation in size of less than $3 \mathrm{~nm}$ of the main peak's hydrodynamic radius was considered as being acceptable. In parallel, the apparition of a peak different from infliximab main peak for which intensity percentage was superior to $10 \%$ was considered as being unacceptable.

\subsubsection{Size exclusion chromatography (SEC)}

Size exclusion chromatography allows the evaluation of monoclonal antibody aggregation or fragmentation. The chromatographic separation was performed by liquid chromatography (LC), using a LC-2010-A HT with integrated controller, pump, autosampler, oven and UV-VIS dectector (Shimadzu Corporation, Marne la Vallée, France). Two LC separation columns TSK - GEL ${ }^{\circledR}$ G3000SWXL columns (7.8 $\mathrm{mm} \times 30 \mathrm{~cm} \times 5 \mu \mathrm{m}$, TOSOH Bioscience), purchased from Interchim (Montluçon, France) were used, mounted in series. A sample volume of $100 \mu \mathrm{l}$ was injected into the system and then eluted using an isocratic flow $\left(\mathrm{Na}_{2} \mathrm{SO}_{4} 0.1 \mathrm{M} \mathrm{Na}_{2} \mathrm{HPO}_{4} 0.1 \mathrm{M}\right.$ and $0.05 \% \mathrm{~m} / \mathrm{w} \mathrm{NaN}$ in water, buffered at $\mathrm{pH}$ 7) at a 
flowrate of $0.6 \mathrm{~mL} / \mathrm{min}$, at a set temperature of $25^{\circ} \mathrm{C}$. The detection wavelength was set up at $280 \mathrm{~nm}$. Obtained SEC chromatograms must conform to reference $\left(D_{0}\right)$ SEC chromatogram (monomer $\geq 98 \%$ ). However, apparition of other species (oligomer or fragment) was followed, when applicable.

\subsubsection{Chemical stability analysis}

\subsubsection{1 pH and osmolality}

pH measurements were made using a SevenMultiTM pH-meter with an InLabTM Micro Pro glass electrode (Mettler-Toledo, Viroflay, France). Osmolality was measured for each solution using an osmometer Model 2020 Osmometer ${ }^{\circledR}$ (Advanced instruments Inc, Radiometer, SAS, Neuilly Plaisance).

$\mathrm{pH}$ measurements were considered to be acceptable if they did not vary by more than $1 \mathrm{pH}$ unit from initial measure. Osmolality measurements are to be interpreted with regards to the potential modification of other parameters and for the purpose of this study were considered to be acceptable if they did not vary by more than $10 \mathrm{mosmol} / \mathrm{kg}$ from $\mathrm{D}_{0}$ values.

\subsubsection{Cation exchange chromatography (CEX)}

Cation exchange chromatography is used to separate different isoforms of infliximab. The chromatographic separation was performed by liquid chromatography (LC), using a LC-2010-AHT with integrated controller, pump, autosampler, oven and UV-VIS dectector (Shimadzu Corporation, Marne la Vallée, France). All analyses were performed on a TSKgel CM-STAT column (4.6 mm x 100 mm x $7 \mu \mathrm{m}$, TOSOH Bioscience), purchased from Interchim (Montluçon, France). Buffer A was prepared with $20 \mathrm{mM}$ MES, and buffer B was prepared with $20 \mathrm{mM}$ MES, $0.5 \mathrm{M} \mathrm{NaCl}$. For each buffer the $\mathrm{pH}$ was adjusted to 5.6 using $1 \mathrm{~N} \mathrm{NaOH}$ solution. The injected sample volume was of $100 \mu \mathrm{L}$ and elution parameters were the following: flow rate of $1 \mathrm{~mL} / \mathrm{min}$ using a gradient composed of $98 \%$ of phase $\mathrm{A}$ and $2 \%$ of phase $\mathrm{B}$ reaching 50\% phase $A$ and $50 \%$ phase $B$ in 35 minutes, then the column was equilibrated with the initial mobile phase for 10 minutes between each analysis. Analysis temperature was set at $35^{\circ} \mathrm{C}$. The detection wavelength was set up at $280 \mathrm{~nm}$.

Obtained CEX chromatograms must conform to reference $\left(D_{0}\right)$ CEX chromatogram. The distribution of each ionic variant was expressed in percentage of total area under curve (AUC). Any variation under $3 \%$ was considered to be acceptable. 


\subsubsection{Structural analysis}

\subsubsection{Peptide mapping}

Peptide mapping allows the study of infliximab's primary structure. $500 \mu \mathrm{L}$ of the solution $(250 \mu \mathrm{L}$ for the $2 \mathrm{mg} / \mathrm{mL}$ solutions), were denatured with $\mathrm{GnHCl}$ (final concentration 6M) in 0,119 M Tris $\mathrm{HCl}$ buffer at $\mathrm{pH}=8.5$ and reduced with $2 \mathrm{mM}$ DTT. Denaturation and reduction were performed together for $60 \mathrm{~min}$ at $37^{\circ} \mathrm{C}$. Samples were then alkylated by $50 \mathrm{mM}$ iodoacetic acid for $15 \mathrm{~min}$ at room temperature protected from light. Tris $\mathrm{HCl}$ buffer was removed by using a spin filter $10 \mathrm{kDa}$ molecular weight cut-off (Millipore, Molsheim, France). After 20 min centrifugation at 4000 rpm, supernatant was completed up to $3.5 \mathrm{~mL}$ with $100 \mathrm{mM}$ ammonium carbonate buffer ( $\mathrm{pH}=7.6)$. Spin filters were centrifugated again $20 \mathrm{~min}$ at $4000 \mathrm{rpm}$. The digestion step was performed with an acetylated trypsin ratio 1:20 (Trypsin / Infliximab, weight/weight) for $14 \mathrm{~h}$ overnight at $37^{\circ} \mathrm{C}$. Before chromatographic analysis, samples were recovered from digestion step and completed to $400 \mu \mathrm{L}$ with $0.1 \%$ TFA in water. The reaction was quenched by storing samples at $5^{\circ} \mathrm{C}$ inside the refrigerated autosampler, and $20 \mu \mathrm{L}$ of each sample were injected into the column.

The chromatographic separation was performed by liquid chromatography (LC), using a LC-2030C with integrated controller, pump, autosampler, oven and UV-VIS dectector (Shimadzu Corporation, Marne la Vallée, France). The separation was performed on a C18 Nucleosil column (250 mm x $3 \mathrm{~mm}, 5$ $\mu \mathrm{m}$, Macherey Nagel, France). Mobile phase was composed of $0.1 \%$ TFA in water (phase A) and $0.09 \%$ TFA in acetonitrile (phase B). Elution started with a gradient $95 \%$ phase $A$ and $5 \%$ phase B. A linear gradient was run from $5 \%$ to $40 \%$ of phase B in $140 \mathrm{~min}$. The flowrate was set to $1 \mathrm{ml} / \mathrm{min}$ and column oven temperature at $40^{\circ} \mathrm{C}$. The detection wavelength was set up at $215 \mathrm{~nm}$. A postrun treatment was done by subtracting the chromatogram of the trypsin solution.

Obtained peptide mapping chromatograms must conform to reference $\left(D_{0}\right)$ chromatogram. Minor and unreproducible variations in the peptide mapping profile (eg. slight retention time variations, intensity variations) were considered to be acceptable. Major reproducible differences, like the appearance or disappearance of a peak, were considered to be unacceptable. 


\subsubsection{Second derivative Fourier Transform Infrared Spectroscopy (FTIR)}

The secondary structure of infliximab was monitored by second derivative FTIR in amide I region $\left(1600-1700 \mathrm{~cm}^{-1}\right)$ using an Avatar 320 (Nicolet, Thermo Electron, Courtaboeuf Cedex, France) equipped with a transmission cell with $25 \mathrm{~mm} \mathrm{BaF}_{2}$ windows. All acquisitions were treated with Omnic software. For FTIR analysis, samples of each concentration were concentrated up to $40 \mathrm{mg} / \mathrm{mL}$ using a spin filter $10 \mathrm{kDa}$ molecular weight cut-off (Millipore, Molsheim, France).

Obtained FT-IR spectra must conform to reference $\left(D_{0}\right)$ profiles. A shift in maxima's and minima's wavenumbers inferior to $2 \mathrm{~cm}^{-1}$ was considered to be acceptable.

\subsubsection{Second derivative UV spectroscopy}

Tertiary structure was studied by second derivative UV spectroscopy. All spectrums were acquired on a Spectrophotometer UV/VIS/NIR Jasco V-670 (Jasco France, Bouguenais, France), using $1 \mathrm{~cm}$ pathlength quartz cuvettes and the measurement wavelength range was set between 250 and $350 \mathrm{~nm}$. All acquisition data were treated with Spectra manager II software.

Obtained second derivative ultraviolet spectra must conform to reference $\left(D_{0}\right)$ spectra. A shift in maxima's and minima's wavelengths inferior to $2 \mathrm{~nm}$ was considered to be acceptable.

\subsubsection{Total protein quantification}

Protein content per vial was estimated by measuring absorbance at $280 \mathrm{~nm}$ [16] of Inflectra ${ }^{\circledR} 10$ $\mathrm{mg} / \mathrm{mL}$ solutions diluted to $0.4 \mathrm{mg} / \mathrm{mL}$. All data were acquired on a spectrophotometer UV/VIS/NIR Jasco V-670 (Jasco France, Bouguenais, France), using $1 \mathrm{~cm}$ pathlength quartz cuvettes. Protein content was calculated using the Beer-Lambert law. According to the manufacturer instructions, protein content was considered to be acceptable when between $90 \%$ and $110 \%$ of theoretical concentration.

\subsubsection{Data analysis - acceptability criteria}

The study was conducted following methodological guidelines issued by the International Conference on Harmonisation for stability studies (ICH guidelines for stability $[9,11]$ and specifications for Biotechnological/Biological products [10]), Bardin et al., 2011 [8], the European Pharmacopeia [17] and recommendations issued by the French Society of Clinical Pharmacy (SFPC) and the Evaluation and Research Group on Protection in Controlled Atmosphere (GERPAC) [18]. , French Society and European Society of Oncology Pharmacy[19]. NHS guidance [20] and INFLECTRA ${ }^{\circledR}$ specifications (provided by Pfizer ${ }^{\circledR}$ ) were also taken into account. 


\section{Results}

\subsection{Visual inspection}

At $D_{0}$, all infliximab samples were limpid, colourless and no visible particles were observed. Throughout the study, no evolution was noticed for the samples stored at $5^{\circ} \mathrm{C}$ and $25^{\circ} \mathrm{C}$. After complete thawing, no evolution from $D_{0}$ was noticed with any storage condition.

\subsection{Turbidity}

Throughout the study, for each concentration and conservation condition, the Al remained within acceptability criteria, with a maximum of $1.761,0.640$ and 0.660 for respectively the $10 \mathrm{mg} / \mathrm{mL}, 2 \mathrm{mg} / \mathrm{mL}$ solutions and $0.4 \mathrm{mg} / \mathrm{mL}$ infliximab solutions. For every condition, Al values remained below acceptability limit even if there was an important variation between samples.

\subsection{Subvisible particles counting}

Larger than $10 \mu \mathrm{m}$ subvisible particle count was out of acceptability criteria only after freezingthawing of $0.4 \mathrm{mg} / \mathrm{mL}$ infliximab solutions (Figure 1). At D0, >25 $\mu \mathrm{m}$ subvisibles particles counting revealed $9 \pm 4$ particles $/ \mathrm{mL}$ for $0.4 \mathrm{mg} / \mathrm{mL}$ infliximab solutions, $1 \pm 0$ particles $/ \mathrm{mL}$ for $2 \mathrm{mg} / \mathrm{mL}$ infliximab solutions and 24 particles $/ \mathrm{mL}$ in $10 \mathrm{mg} / \mathrm{mL}$ infliximab solutions. The number of particles was more important with $10 \mathrm{mg} / \mathrm{mL}$ samples than with diluted solutions, respectively 127 and 24 particles $/ \mathrm{mL}$ superior to $10 \mu \mathrm{m}$ and superior to $25 \mu \mathrm{m}$. For each temperature and analytical time, the number of particles/mL did not significantly increase.

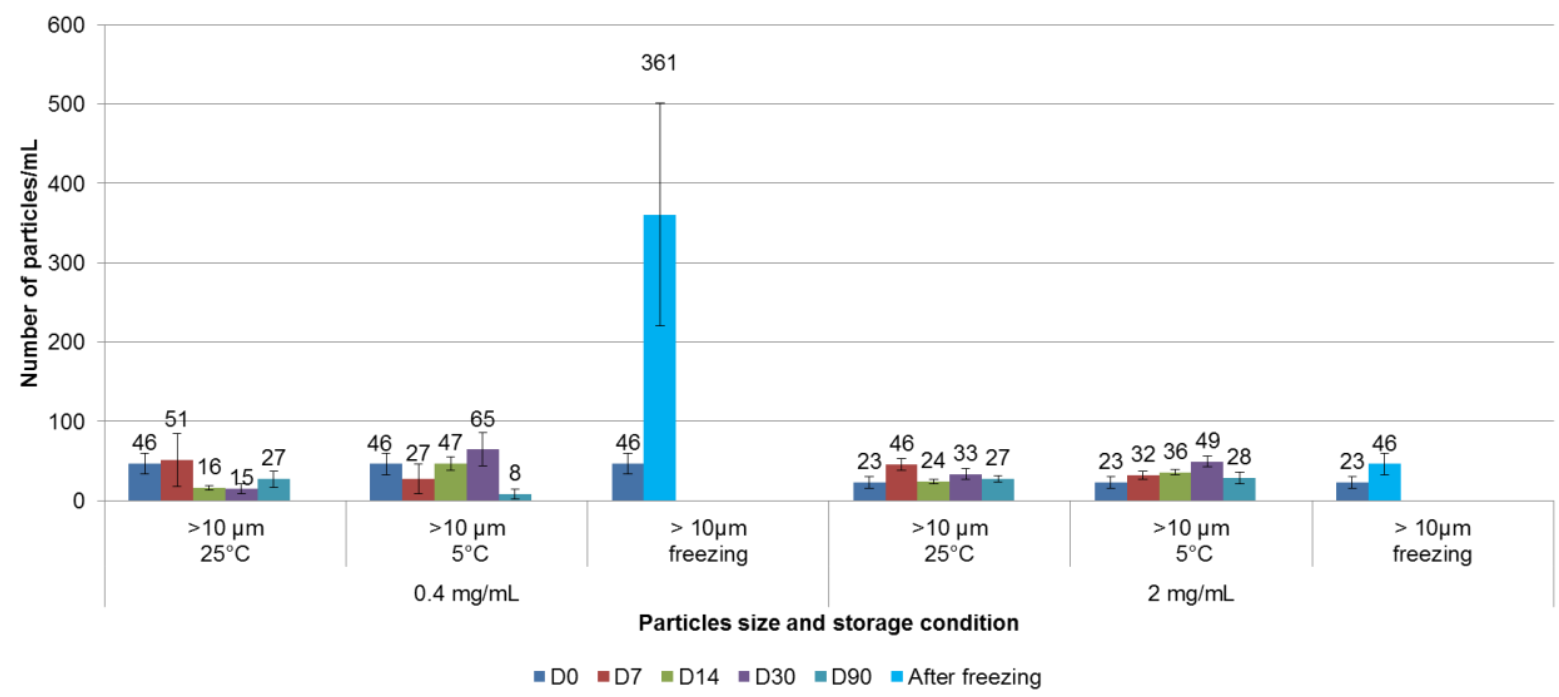

Figure 1 : Number of particles $>10 \mu \mathrm{m}$ for $0.4 \mathrm{mg} / \mathrm{mL}$ and $2 \mathrm{mg} / \mathrm{mL}$ infliximab solutions in $0.9 \%$ $\mathrm{NaCl}$ infusion bags at each storage temperature (mean $\pm S D, n=3$ ) 
The counting of subvisible particles of size superior to $10 \mu \mathrm{m}$ and superior to $25 \mu \mathrm{m}$ in diluted solutions ( 0.4 and $2 \mathrm{mg} / \mathrm{mL}$ ) was over European Pharmacopeia limit (respectively 25 particles $/ \mathrm{mL}$ and 3 particles $/ \mathrm{mL}$ ) while it remained within European Pharmacopeia limits for the $10 \mathrm{mg} / \mathrm{mL}$ solutions as their nominal volume was lower than $100 \mathrm{~mL}$ (respectively 6000 particles/container and 600 particles/container).

\subsection{Nanoparticles size determination}

Infliximab nanoparticles sizes estimated by DLS are shown in Table 1. Hydrodynamic diameter was out of acceptability criteria only after freeze-thawing of $10 \mathrm{mg} / \mathrm{mL}$ infliximab solutions, as an increase of $3.17 \mathrm{~nm}$ was noticed after a single freeze-thawing cycle.

Table 1: Infliximab nanoparticles hydrodynamic diameter evolution over time and storage conditions for each studied concentration estimated by DLS (ND: not determined).

\begin{tabular}{|c|c|c|c|c|c|c|c|c|c|c|}
\hline \multirow[t]{2}{*}{$\begin{array}{l}\text { Storage } \\
\text { time } \\
\text { (days) }\end{array}$} & \multicolumn{3}{|c|}{$\begin{array}{c}10 \mathrm{mg} / \mathrm{mL} \\
\text { mean size } \pm \mathrm{SD} \\
(\mathrm{nm})\end{array}$} & \multirow{2}{*}{\multicolumn{3}{|c|}{$\begin{array}{c}2 \mathrm{mg} / \mathrm{mL} \\
\text { mean size } \pm \mathrm{SD} \\
(\mathrm{nm}) \\
\text { Freezing } \\
\end{array}$}} & \multicolumn{3}{|c|}{$\begin{array}{c}0.4 \mathrm{mg} / \mathrm{mL} \\
\text { mean size } \pm \mathrm{SD} \\
(\mathrm{nm})\end{array}$} & \multirow[t]{2}{*}{$\begin{array}{c}\text { Mean PDI } \\
\pm \text { SD }\end{array}$} \\
\hline & & & & & & & & & & \\
\hline DO & 12.22 & \pm & 2.66 & 16.83 & \pm & 5.06 & 12.58 & \pm & 2.49 & $0.202 \pm 0.048$ \\
\hline D3 & 15.39 & \pm & 5.76 & 17.68 & \pm & 4.86 & 14.38 & \pm & 5.00 & $0.190 \pm 0.043$ \\
\hline \multicolumn{11}{|c|}{$5^{\circ} \mathrm{C}$} \\
\hline D0 & 13.45 & \pm & 2.69 & 16.83 & \pm & 5.06 & 12.58 & \pm & 2.49 & $0.203 \pm 0.049$ \\
\hline D7 & 12.66 & \pm & 3.01 & 16.22 & \pm & 4.91 & 13.56 & \pm & 3.94 & $0.160 \pm 0.023$ \\
\hline D14 & 14.91 & \pm & 5.80 & 16.81 & \pm & 5.54 & 12.62 & \pm & 2.82 & $0.193 \pm 0.049$ \\
\hline D30 & 13.58 & \pm & 5.63 & 16.53 & \pm & 5.29 & 12.98 & \pm & 3.76 & $0.189 \pm 0.048$ \\
\hline D90 & \multicolumn{3}{|c|}{ ND } & 17.78 & \pm & 5.83 & 12.82 & \pm & 3.81 & $0.156 \pm 0.035$ \\
\hline \multicolumn{11}{|c|}{$25^{\circ} \mathrm{C}$} \\
\hline DO & 13.45 & \pm & 2.69 & 16.83 & \pm & 5.06 & 12.58 & \pm & 2.49 & $0.210 \pm 0.041$ \\
\hline D7 & 12.88 & \pm & 3.88 & 16.41 & \pm & 4.63 & 12.61 & \pm & 3.27 & $0.160 \pm 0.023$ \\
\hline D14 & 13.76 & \pm & 4.86 & 16.65 & \pm & 5.01 & 12.72 & \pm & 2.82 & $0.170 \pm 0.052$ \\
\hline D30 & 12.73 & \pm & 3.48 & 16.72 & \pm & 5.33 & 13.23 & \pm & 4.48 & $0.174 \pm 0.045$ \\
\hline D90 & \multicolumn{3}{|c|}{ ND } & 17.40 & \pm & 5.61 & 13.00 & \pm & 2.92 & $0.162 \pm 0.025$ \\
\hline
\end{tabular}




\subsection{Size exclusion chromatography}

The main peak, corresponding to infliximab monomeric form (elution time (et) $=27.3 \mathrm{~min} \pm 0.02$ min) remained above $98 \%$ of total Area Under Curve (AUC) throughout the studies for all conditions. A second peak (et $=23.2 \mathrm{~min} \pm 0.2 \mathrm{~min}$ ) corresponding to a high molecular weight polymer (HMWP) was observed from $D_{0}$ onwards but did not significantly vary overtime for any of the conditions. However, a fragment was detected with a et $=33.6 \mathrm{~min} \pm 0.1 \mathrm{~min}$, and its $A \cup C$ percentage increased overtime for samples of all three concentrations when stored at $25^{\circ} \mathrm{C}$, but not for those stored at $5^{\circ} \mathrm{C}$ and at $-20^{\circ} \mathrm{C}$ (the peak remained unquantifiable) (see supplementary data, Table A). As an example, SEC chromatograms of the $0.4 \mathrm{mg} / \mathrm{mL}$ infliximab solutions at $D_{0}$ are compared to chromatograms of the last analytical of each storage condition ( $D_{90}$ for storage at $5^{\circ} \mathrm{C}$ and $25^{\circ} \mathrm{C}$ and $D_{3}$ after freezing) in Figure 2. The main peak corresponding to infliximab monomeric form represented $99.29 \% \pm 0.03 \%$ of total AUC. At $D_{90}$ of the $25^{\circ} \mathrm{C}$ storage, the fragmented form reached its maximum of $0.48 \% \pm 0.08 \%$ of total AUC while no variation from $\mathrm{D}_{0}$ was observed after storage at $5^{\circ} \mathrm{C}$ or $-20^{\circ} \mathrm{C}$.

Monomeric form at $D_{0}$ for infliximab solutions at $2 \mathrm{mg} / \mathrm{mL}$ and $10 \mathrm{mg} / \mathrm{mL}$ were respectively of $99.15 \% \pm 0.00 \%$ and $99.19 \% \pm 0.02 \%$ and the increase in fragmented form was observed for all $25^{\circ} \mathrm{C}$ storage conditions with respective values of $0.13 \% \pm 0.00 \%$ and $0.10 \% \pm 0.00 \%$ at $D_{90}$ while no modification was observed after storage at $5^{\circ} \mathrm{C}$ or $-20^{\circ} \mathrm{C}$.

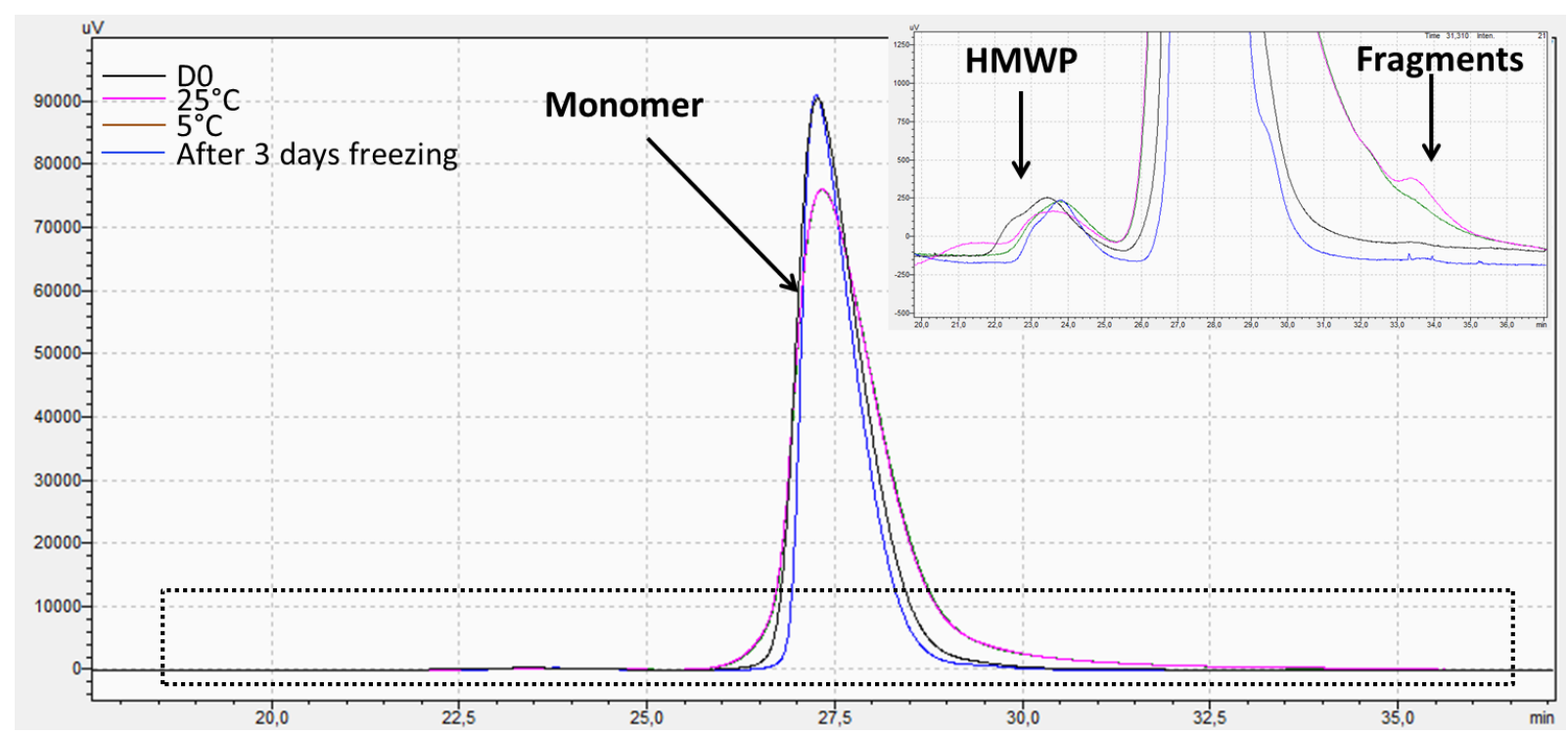

Figure 2: SEC profile evolution of $0.4 \mathrm{mg} / \mathrm{mL}$ infliximab solutions at $D_{0}$ compared to $D_{90}$ after a 90 days storage at $5^{\circ} \mathrm{C}$ and $25^{\circ} \mathrm{C}$ and after a freeze-thawing cycle of 3 days 


\section{6 $\mathrm{pH}$ and osmolality}

Initial pH values for the different conditions are shown in Table 2. For all studies, no variations of more than $\pm 0.27 \mathrm{pH}$ units and $4.33 \mathrm{mosmol} / \mathrm{kg}$ were observed from $D_{0}$ values onwards. Throughout the study and for both conservation conditions, obtained $\mathrm{pH}$ and osmolality results meet acceptability criteria (no significant variation).

Table 2 : $\mathrm{pH}$ and osmolality values at $\mathrm{D}_{0}$ for every conditioning condition (mean $\pm \mathrm{SD}, \mathrm{n}=3$ )

\begin{tabular}{ccc} 
& Mean pH at DO \pm SD & $\begin{array}{c}\text { Mean osmolality at DO } \pm \text { SD } \\
\text { mosmol } / \mathrm{kg}\end{array}$ \\
\hline $10 \mathrm{mg} / \mathrm{mL}$ in original glass vials & $6.98 \pm 0.07$ & $280.33 \pm 3.06$ \\
$0.4 \mathrm{mg} / \mathrm{mL}$ in NaCl bags & $6.92 \pm 0.05$ & $280.33 \pm 0.58$ \\
$2 \mathrm{mg} / \mathrm{mL}$ in NaCl bags & $7.09 \pm 0.01$ & $261.67 \pm 1.53$ \\
\hline
\end{tabular}

\subsection{Cation exchange chromatography}

CEX chromatograms presented a specific profile with 6 different peaks. None of the studied conditions led to new acidic or basic variants appearance. As an example, CEX results of $0.4 \mathrm{mg} / \mathrm{mL}$ infliximab solutions are shown in Figure 3. A significant decrease of peak $4(-5.36 \%)$ and increase of peak $1(+5.47 \%)$ was simultaneously observed at $\mathrm{D}_{90}$ when sample were stored at $25^{\circ} \mathrm{C}$. Modifications until $\mathrm{D}_{30}$ included were not significant. When stored at $5^{\circ} \mathrm{C}$, peak proportion of total AUC did not vary by more than $2.75 \%$. A similar evolution profile was observed for other storage and concentration conditions. The $10 \mathrm{mg} / \mathrm{mL}$ solutions at $25^{\circ}$ condition showed a coupled decrease of peak $4(-3.34 \%)$ and increase of peak $1(+3.77 \%)$ from $D_{14}$ included.

After a freeze-thawing cycle, a decrease of peak 4 and an increase of peak 1 percentage of total AUC was observed when $10 \mathrm{mg} / \mathrm{mL}$ infliximab samples were frozen for 3 days. CEX chromatograms of 0.4 $\mathrm{mg} / \mathrm{mL}$ Infliximab solutions did not show any significant variation from $\mathrm{D}_{0}$ (Figure 3 . B).

When stored at $5^{\circ} \mathrm{C}$, all three studied infliximab concentrations remained within acceptability criteria throughout the study (no variation of variants percentage). 

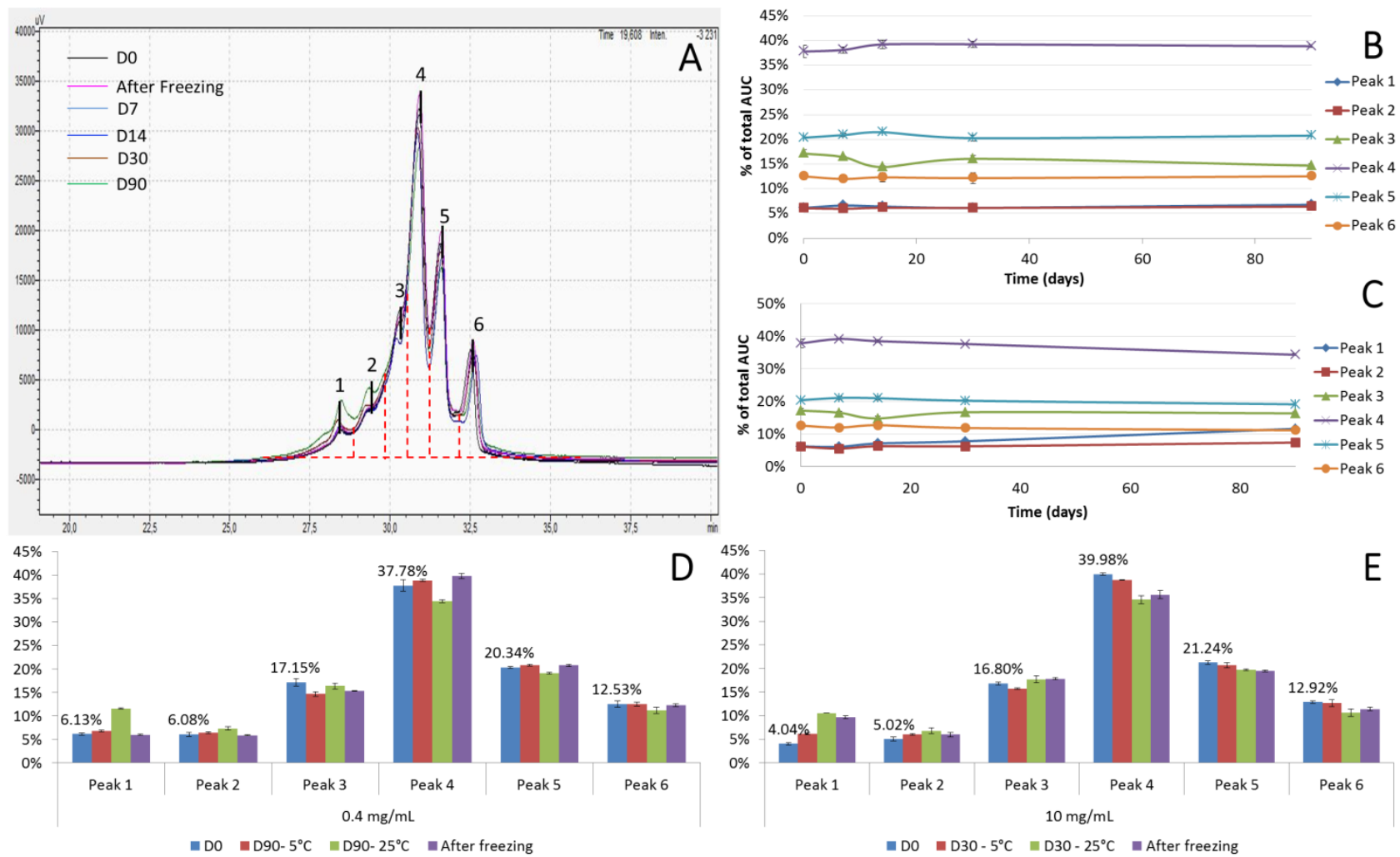

Figure 3 : Cation Exchange chromatograms at each analytical time of $0.4 \mathrm{mg} / \mathrm{mL}$ infliximab solutions stored at $25^{\circ} \mathrm{C}(\mathrm{A})$, evolution of peaks percentage from total $A U C$ (mean $\pm S D, n=3$ ) for the $5^{\circ} \mathrm{C}\left(\mathrm{B}\right.$ ) and $25^{\circ} \mathrm{C}$ (C) storage condition, comparison of each peaks percentage of total AUC at the final analytical time for each storage condition of $0.4 \mathrm{mg} / \mathrm{mL}$ infliximab solutions (D) and $10 \mathrm{mg} / \mathrm{mL}$ infliximab solutions (E).

\subsection{Peptide mapping}

Peptide mapping chromatograms of $10 \mathrm{mg} / \mathrm{mL}$ infliximab solutions at $D_{0}$ is shown in Figure 4 . Despite being very similar, minor modifications from $D_{0}$ profile were observed at $D 30$ for both temperature conditions (supplementary data, figure A). After freezing, peptide map was qualitatively different from DO (supplementary data, figure B)

For all other conditions of temperature and concentration, peptide map was not significantly different from DO at any time. 


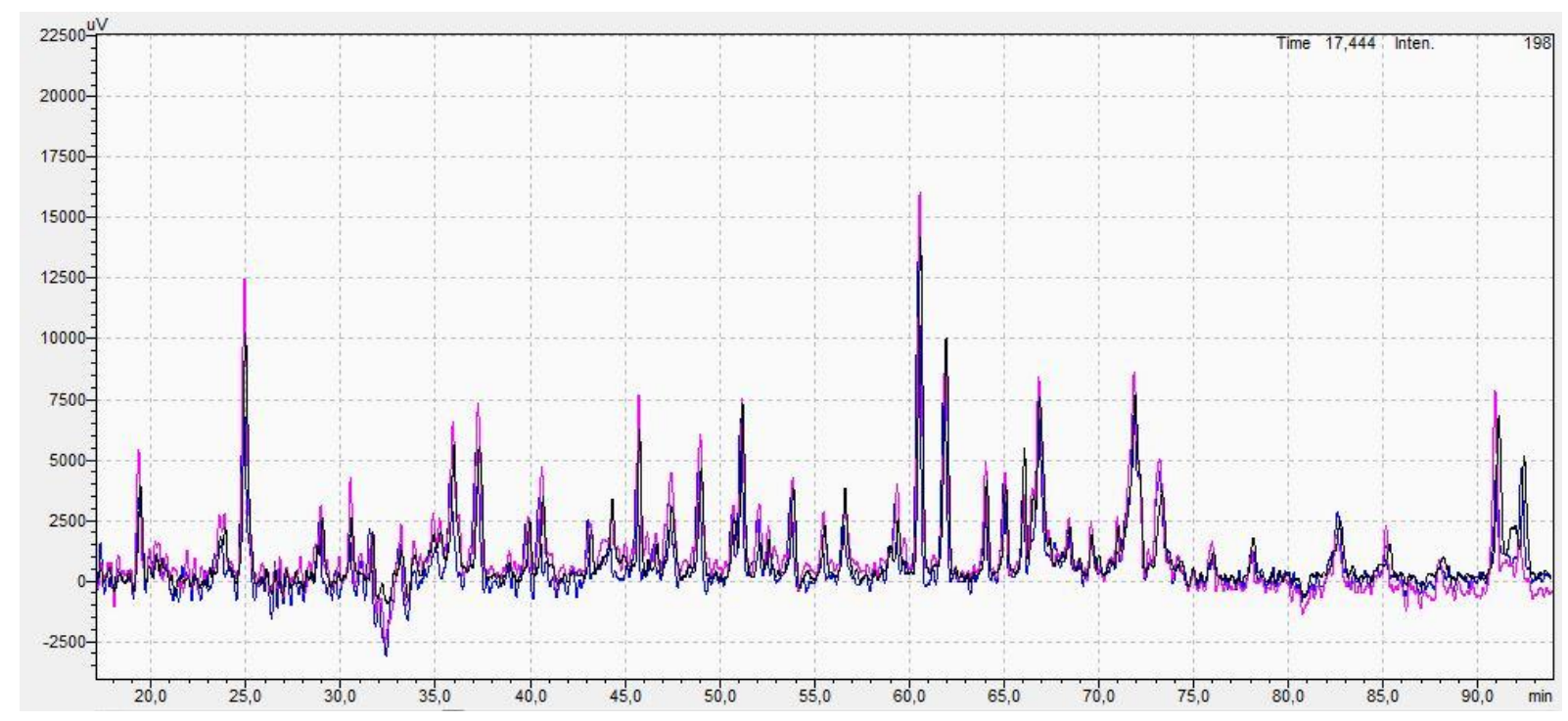

Figure 4 : peptide mapping chromatogram of $10 \mathrm{mg} / \mathrm{mL}$ infliximab solutions at $D 0$. ( $n=3$, black, blue and pink chromatograms corresponding to the triplicate)

\subsection{Second derivative FT-IR}

Second derivative FTIR spectra of $0.4 \mathrm{mg} / \mathrm{mL}$ infliximab solutions at $D_{0}$ and compared to those at the final analytical time of each condition is shown in Figure 5. No modification was observed from $D_{0}$ to $D_{90}$ or after a freeze-thawing cycle, nor for any other concentration and storage conditions at any time.

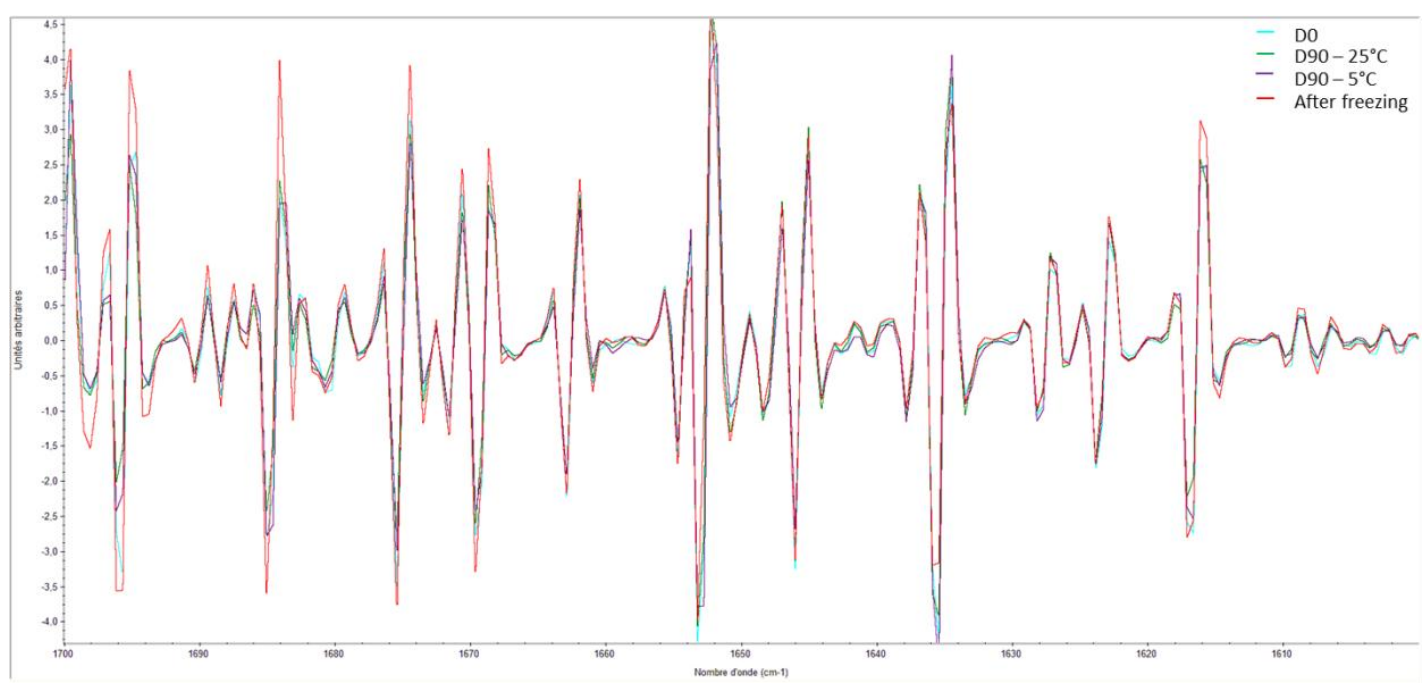

Figure 5 : Second derivative FTIR spectra of $0.4 \mathrm{mg} / \mathrm{mL}$ infliximab solutions at the final analytical time of each temperature condition. 


\subsection{Second derivative UV spectroscopy}

Second derivative UV spectra of $0.4 \mathrm{mg} / \mathrm{mL}$ infliximab solutions at $D_{0}$ and compared to those at the final analytical time of each condition is shown in Figure 6. No modification was observed from $D_{0}$ to $\mathrm{D}_{90}$ or after a freeze-thawing cycle, nor for any other concentration and storage conditions at any time.

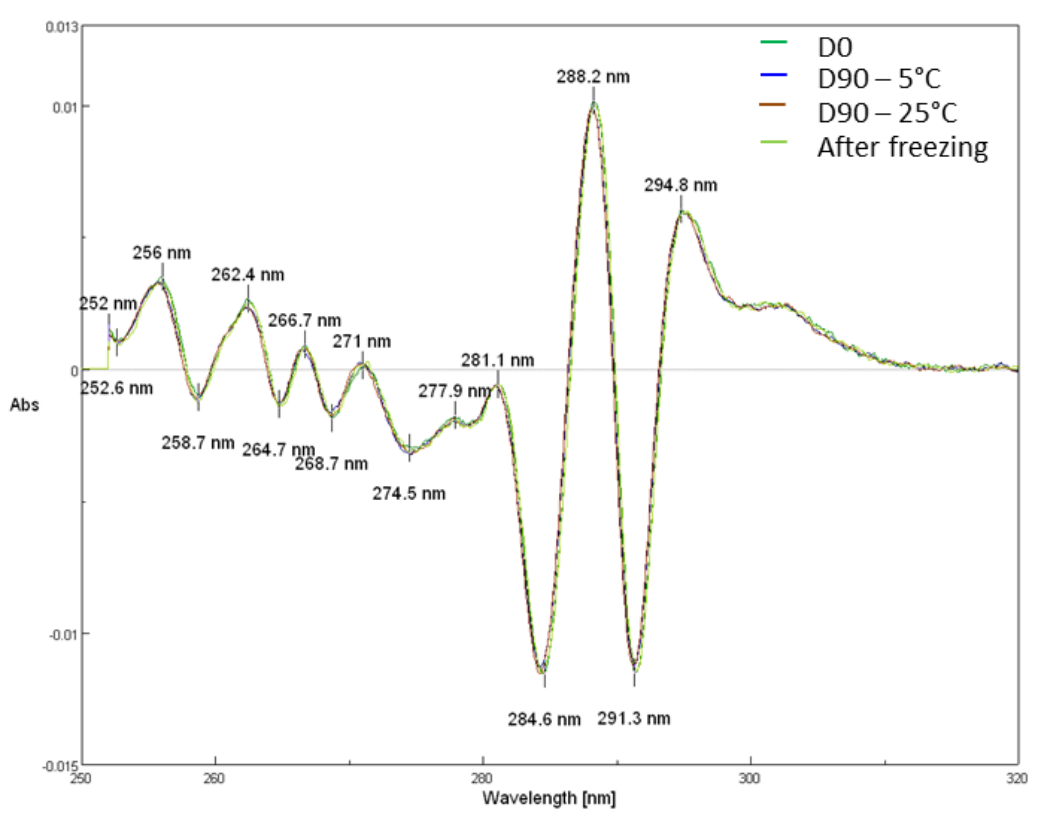

Figure 6 : Second derivative UV spectra of $0.4 \mathrm{mg} / \mathrm{mL}$ infliximab solutions at the final analytical time of each temperature condition.

\subsection{Total protein quantification}

Quantification for every preparation and storage conditions is shown in Figure 7. For $0.4 \mathrm{mg} / \mathrm{mL}$ infliximab solutions concentration was respectively of $0.39 \pm 0.01 \mathrm{mg} /$ at $D_{0}$. For $2 \mathrm{mg} / \mathrm{mL}$ infliximab solutions, concentration was $1.75 \pm 0.04 \mathrm{mg} / \mathrm{mL}$ and for $10 \mathrm{mg} / \mathrm{mL}$ infliximab solutions, the result is expressed as the amount of protein/vial and was of $9.05 \pm 0.79 \mathrm{mg} / \mathrm{vial}$ at $D_{0}$.

Over the study, for each concentration and temperature condition, results remained between $90 \%$ and $110 \%$ of theoretical concentration. 


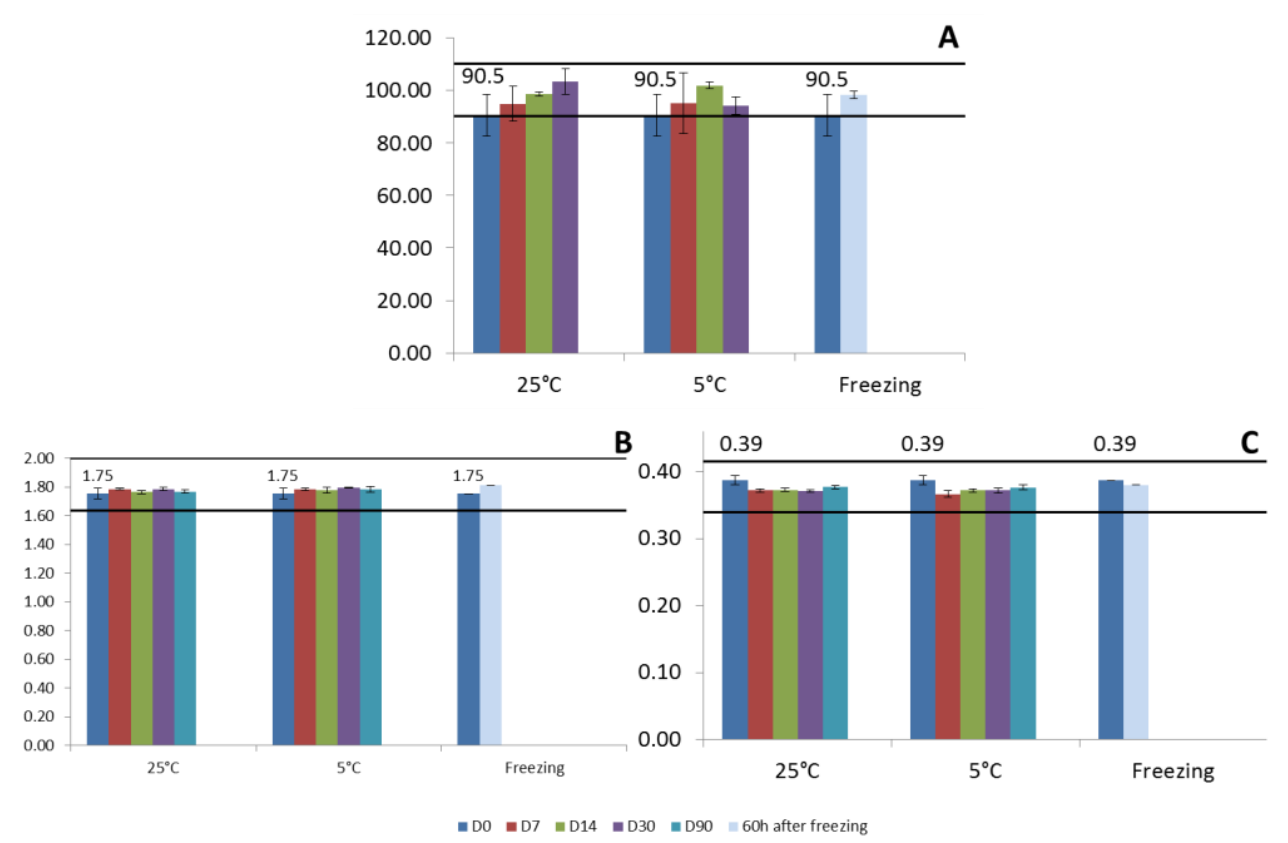

Figure 7 : Total protein quantification of infliximab solutions: $10 \mathrm{mg} / \mathrm{mL}(\mathrm{A}), 0.4 \mathrm{mg} / \mathrm{mL}$ (B), and 2 $\mathrm{mg} / \mathrm{mL}$ (C) for each conservation temperature condition

\subsection{Synthesis}

All signs of instability observed are presented in Table 3.

Table 3 : Summary of stability result for each analytical technique and conditions.

\begin{tabular}{|c|c|c|c|c|c|c|c|c|c|}
\hline & \multicolumn{3}{|c|}{$10 \mathrm{mg} / \mathrm{mL}$} & \multicolumn{3}{|c|}{$2 \mathrm{mg} / \mathrm{mL}$} & \multicolumn{3}{|c|}{$0.4 \mathrm{mg} / \mathrm{mL}$} \\
\hline & Freezing & $5^{\circ} \mathrm{C}$ & $25^{\circ} \mathrm{C}$ & Freezing & $5^{\circ} \mathrm{C}$ & $25^{\circ} \mathrm{C}$ & Freezing & $5^{\circ} \mathrm{C}$ & $25^{\circ} \mathrm{C}$ \\
\hline \multicolumn{10}{|c|}{ Physical } \\
\hline Visual exam & $\checkmark$ & $\checkmark$ & $\checkmark$ & $\checkmark$ & $\checkmark$ & $\checkmark$ & $\checkmark$ & $\checkmark$ & $\checkmark$ \\
\hline Turbidity & $\checkmark$ & $\checkmark$ & $\checkmark$ & $\checkmark$ & $\checkmark$ & $\checkmark$ & $\checkmark$ & $\checkmark$ & $\checkmark$ \\
\hline HIAC & $\checkmark$ & $\checkmark$ & $\checkmark$ & $x$ & $\checkmark$ & $\checkmark$ & $x$ & $\checkmark$ & $\checkmark$ \\
\hline DLS & $x$ & $\checkmark$ & $\checkmark$ & $\checkmark$ & $\checkmark$ & $\checkmark$ & $\checkmark$ & $\checkmark$ & $\checkmark$ \\
\hline SEC & $\checkmark$ & $\checkmark$ & $\begin{array}{c}\checkmark \\
\text { oligomers at } \\
\text { D14 } \\
\end{array}$ & $\checkmark$ & $\checkmark$ & $\begin{array}{c}\checkmark \\
\text { oligomers at } \\
\text { D14 } \\
\end{array}$ & $\checkmark$ & $\checkmark$ & $\begin{array}{c}\checkmark \\
\text { oligomers at } \\
\text { D14 } \\
\end{array}$ \\
\hline \multicolumn{10}{|c|}{ Chemical } \\
\hline $\mathrm{pH} / \mathrm{osmo}$ & $\checkmark$ & $\checkmark$ & $\checkmark$ & $\checkmark$ & $\checkmark$ & $\checkmark$ & $\checkmark$ & $\checkmark$ & $\checkmark$ \\
\hline CEX & $x$ & $\checkmark$ & $\begin{array}{c}\boldsymbol{x} \\
7 \text { days }\end{array}$ & $\checkmark$ & $\checkmark$ & $\begin{array}{c}\boldsymbol{x} \\
30 \text { days }\end{array}$ & $\checkmark$ & $\checkmark$ & $\begin{array}{c}\mathbf{x} \\
30 \text { days }\end{array}$ \\
\hline \multicolumn{10}{|c|}{ Structural } \\
\hline $\begin{array}{l}\text { Peptide } \\
\text { mapping }\end{array}$ & $x$ & $\begin{array}{c}\boldsymbol{x} \\
14 \text { days }\end{array}$ & $\begin{array}{c}\boldsymbol{x} \\
14 \text { days }\end{array}$ & $\checkmark$ & $\checkmark$ & $\checkmark$ & $\checkmark$ & $\checkmark$ & $\checkmark$ \\
\hline SD-FTIR & $\checkmark$ & $\checkmark$ & $\checkmark$ & $\checkmark$ & $\checkmark$ & $\checkmark$ & $\checkmark$ & $\checkmark$ & $\checkmark$ \\
\hline SD-UV & $\checkmark$ & $\checkmark$ & $\checkmark$ & $\checkmark$ & $\checkmark$ & $\checkmark$ & $\checkmark$ & $\checkmark$ & $\checkmark$ \\
\hline
\end{tabular}




\section{Discussion}

Our study presents new information about the stability of concentrated and diluted infliximab solutions, pertinent to regular pharmaceutical and clinical use. A large panel of analytical techniques was used to assess the effect of storage temperature and dilution on the physicochemical stability of infliximab solutions as recommended by the international guidelines [11-17]. In forced degradation studies physical degradation is usually the main issue [21], even if it can be associated with chemical degradation under some conditions [22]. However, in this long term storage study, chemical stability appeared to be the most critical point, as after 90 days storage at $25^{\circ} \mathrm{C}$, important chemical modifications and minor physical instabilities were revealed by CEX and SEC for both 0.4 and $2 \mathrm{mg} / \mathrm{mL}$ solutions, however storage at $5^{\circ} \mathrm{C}$ allowed infliximab to remain physicochemically unchanged for up to 90 days included. Freezing caused physical degradation (increased particle levels) for all three concentrations. Stability appeared to be dilution dependent, in addition to temperature dependent. For the $10 \mathrm{mg} / \mathrm{mL}$ infliximab solutions, obtained data is in favour only a 7 days physicochemical stability when stored at $25^{\circ} \mathrm{C}$ after reconstitution with water for injection in original glass vials. When stored at $5^{\circ} \mathrm{C}$, the data is in favour of an extended stability of 14 days. $0.4 \mathrm{mg} / \mathrm{mL}$ and $2 \mathrm{mg} / \mathrm{mL}$ infliximab solutions diluted in $\mathrm{NaCl}$ and stored in Polyolefin (Polypropylene PP) bags were stable up to 30 days at $25^{\circ} \mathrm{C}$ and 90 days at $5^{\circ} \mathrm{C}$

Aggregate formation is normally the main critical point limiting mAbs stability in solutions, and has also been shown to occur after freeze-thawing stress of monoclonal antibodies [23]. Four analytical techniques, that complement each other, were used to assess the aggregation level of infliximab solutions. Sub-visible particles over $10 \mu \mathrm{m}$ and over $25 \mu \mathrm{m}$ were counted by light obscuration (HIAC) and nanoparticles between $0.3 \mathrm{~nm}$ and $10 \mu \mathrm{m}$ were assessed by DLS. SEC was also used to explore aggregation, since this Liquid Chromatography (LC) method is able to separate mAbs monomeric form from the polymeric form (dimeric or more) and fragments. To complete aggregate formation study, turbidity was assessed by calculating an aggregation index based on absorbance at $280 \mathrm{~nm}$ and $350 \mathrm{~nm}$. Without aggregation, absorbance at $350 \mathrm{~nm}$ is almost null, but when aggregates are presents in solution, the UV beam is deflected leading to an increase in absorbance. Those four analytical techniques allowed us to have a global vision of infliximab's aggregation potential, but mAbs stability is not only limited to physical issues. Chemical stability was assessed by CEX which is an LC method separating mAbs charge variants, mainly resulting from the manufacturing process. Osmolality and $\mathrm{pH}$ are part of the chemical stability and were followed because of the clinical impact they could have during the infusion to the patient. Beside the clinical aspect, $\mathrm{pH}$ variations can be responsible of mAbs degradation [24], especially leading to a potential aggregation. In this work primary structure was assessed by performing a peptide map, a chromatographic separation of 
peptides stemming from an enzymatic digestion. Secondary and tertiary structures were characterized by spectroscopic methods, respectively SD-FTIR and SD-UV. However, circular dichroism and fluorescence spectroscopy could have been employed as alternative techniques to assess secondary structure and conformational changes. However, it has been shown that even if circular dichroism can provide complementary information about secondary structure, it is not more efficient than SD-FTIR to highlight small conformational changes that are likely to happen during a stability study [25].

Visual examination has not shown any differences throughout the studies when samples were stored at $5^{\circ} \mathrm{C}$. This result was confirmed by turbidity and subvisibles particles counting analysis, which did not show any increase overtime, indicating the absence of large aggregate formation. The number of particles larger than $10 \mu \mathrm{m}$ and $25 \mu \mathrm{m}$ was over generally above European Pharmacopeia acceptability criteria [15] for 0.4 and $2 \mathrm{mg} / \mathrm{mL}$ solutions, even at $D_{0}$, but since the manufacturer recommends to infuse infliximab with a infusion set equipped with an inline $0.22 \mu \mathrm{m}$ filter which would retain the particles, the clinical impact of such subvisible particles might be negligible as they would be retained before administration. DLS results did not highlight the formation of dimer or smaller than $1 \mu \mathrm{m}$ aggregates since no particles with a significant higher hydrodynamic diameter were detected. As previous studies have shown before [26], hydrodynamic diameter was lower with 0.4 $\mathrm{mg} / \mathrm{mL}$ samples than with $2 \mathrm{mg} / \mathrm{mL}$ (10 $\mathrm{mg} / \mathrm{mL}$ samples were diluted to $0.4 \mathrm{mg} / \mathrm{mL}$ before analysis which explains why they were not larger than $2 \mathrm{mg} / \mathrm{mL}$ particles).

SEC results highlighted the presence of HMWP from $D_{0}$ regardless of the conditions, probably dimers and other size variants that were hardly separable. Those HMWP have already been highlighted by studies [26] made on another infliximab biosimilar (REMSIMA ${ }^{\circledR}$ ). SEC also detected a fragment formation, which was present but under the quantification limit at $D_{0}$ for the $0.4 \mathrm{mg} / \mathrm{mL}$ concentrations. Yet, this fragment increased overtime for every concentration condition at $25^{\circ} \mathrm{C}$, but not at $5^{\circ} \mathrm{C}$. Despite increasing fragment percentages, the monomeric form remained over $99 \%$ of total AUC. Without official recommendations for acceptable degradation of monoclonal antibodies, the critical threshold used was the one set up by the manufacturer (monomer $>98 \%$ of total AUC). None of the analytical techniques used for physical stability evaluation indicated the formation of aggregates during any of the studied conditions. Previous internal intentional degradation studies (data not shown) highlighted that some mAbs degradation products (especially fragments) were hardly separable by SEC. The use of two columns mounted in series allowed us to increase selectivity of the SEC method without using smaller particles packed columns, which even if they possess several advantages like better peak resolution and separation between aggregates and native protein peaks [27], require the use of ultra-high pressure chromatographic systems, whilst using UV detection that was the only option available at our laboratory. However, fluorescence detection based SEC (or CEX) 
would avoid some of the limits of UV based detection, especially by increasing sensitivity which is major issue for monoclonal antibodies

Infliximab presented a CEX profile with 6 peaks sufficiently resolved, the $7^{\text {th }}$ that had been described in other studies $[26,28]$ was visible (between peak 5 and 6 of these studies) but not quantifiable. Mobile phase $\mathrm{pH}$ was adjusted to 5.6 and could explain the differences observed between our chromatograms and other studies. Indeed, acidic variants were better resolved with a pH at 5.6 while basic variants were better visualized at $\mathrm{pH}=6.5$ [29]. In order to make our CEX results comparable to studies already performed with the infliximab biosimilar REMSIMA, the CEX analysis was performed by injecting the intact antibody. However, an enzymatic digestion by papain which split Fc and Fabs of monoclonal antibodies might provide more information about the localisation of potential charge variants. Moreover, the papain digestion could also increase the selectivity of the method by increasing the separation between variants. Another way of increasing specificity is to separate variants with a semi-preparative column, then analyse each fraction one by one.

Charge variants were present even at D0 and corresponded to post-translational modifications resulting in infliximab with zero, one or two C-terminal Lysine associated with a variation of charged glycans [28]. An equilibrium between all those variants was observed at D0. During the studies, no new acidic or basic variants appeared, but the variation observed (increase of acidic variant 1) for all concentration conditions when stored at $25^{\circ} \mathrm{C}$ was a sign a chemical instability. The $3 \%$ threshold corresponded to the limit where variation was considered to be significantly different from analytical variations. Our studies have shown that chemical instability was the principal stability limitation of infliximab solutions during long term storage at $25^{\circ} \mathrm{C}$. Significant modifications arose faster with the 10 $\mathrm{mg} / \mathrm{mL}$ conditions (14 days against 90 days for other conditions), so diluting a mAb solution may be a way to increase chemical stability. However, dilution will also diluted excipients, some of which are known to have a stabilizing effect, like surfactants [24]. On the other side, $10 \mathrm{mg} / \mathrm{mL}$ samples were reconstituted in water for injection while samples at lower concentrations were diluted in $0.9 \% \mathrm{NaCl}$ bags, and it had been shown that the ionic strength may interfere with monoclonal antibodies stability [30].

Modifications in the primary structure were observed through peptide mapping analysis. A minor modification was noticed only in the $10 \mathrm{mg} / \mathrm{mL}$ in glass vials conditions after $D_{30}$. Even though we were not able to accurately characterize the sort of modifications of the peptide map (oxidation, deamidation) without using LC-MS method, LC was sensitive enough to perform a qualitative comparison between samples at DO and samples after storage. A variation in primary structure is often a cause of physical instability, fragmentation or aggregation. Considering the absence of instability it is not surprising that primary structure remained unchanged during the study for all 
concentration and temperature conditions. However, if the units had been exposed to light during the study, maybe certain oxidation modifications might have noticed, as light as been shown to catalyse some modifications [31].

Secondary and tertiary structures were assessed respectively by SD-FTIR and SD-UV spectroscopy and no sign of instability was highlighted. Variations observed with CEX could have been related to a structural modification, but they were either below the sensitivity limits of spectroscopic methods either not related, as Jasper C. et al [23] have shown in FTIR. However, Jasper C. et al. [25] did show that variations in SEC and CEX can be not related to a modification in SD-FTIR spectrum. Previous studies made with other infliximab biosimilars [27,31] assessed the stability of diluted solutions over a study period of 30 days. This study has shown that infliximab diluted in $\mathrm{NaCl}$ polyolefin bags were physically and chemically stable up to 90 days when stored at $5^{\circ} \mathrm{C}$, and 30 days at $25^{\circ} \mathrm{C}$.

Physical and chemical signs of instability were detected when stressing $10 \mathrm{mg} / \mathrm{mL}$ infliximab solutions by freeze-thawing. Variations of nanoparticles hydrodynamic diameter were observed in DLS when infliximab samples were frozen at $10 \mathrm{mg} / \mathrm{mL}$ but were absent when for $0.4 \mathrm{mg} / \mathrm{mL}$ and $2 \mathrm{mg} / \mathrm{mL}$ solutions. This could be explained by aggregation (possible formation of dimers or other HMWP) slightly impacting overall particle size, without modifying any other structural aspect. This result could have been confirmed by SEC but the amount of formed aggregates was probably under the limit of detection (LOD) of the assay. Chemical stability was assessed by CEX and highlighted a correlated variation of two peaks corresponding to the main peak with no C-terminal Lysine [26] (peak 4) and an unidentified acidic variant (peak 1). These modifications were not correlated to a $\mathrm{pH}$ variation and suggested a chemical instability that could be part of a possible aggregation mechanism predicted by DLS. To complete physicochemical analysis, a structural analysis was performed. Secondary and tertiary structures were assessed respectively by SD-FTIR and SD-UV spectroscopy. None of these analytical techniques showed any sign of instability. Peptide mapping was used to characterize primary structure, and highlighted an unexpected change in the complete mapping of infliximab solutions at $10 \mathrm{mg} / \mathrm{mL}$ in glass vials. An analysis of the peptide map by LC-MS could have allowed us to determine what kind of degradation the peptides underwent and determine if the modification of the peptide map was related or not to the potential aggregation phenomenon.

However, infliximab solutions at 0.4 and $2 \mathrm{mg} / \mathrm{mL}$ did not show any sign of chemical instability and hydrodynamic did not vary after freezing. HIAC results suggested an increase in subvisibles particles after freeze-thawing of 0.4 and $2 \mathrm{mg} / \mathrm{mL}$ infliximab solutions, whilst subvisibles particles levels remained unchanged for $10 \mathrm{mg} / \mathrm{mL}$ solutions. This increase was correlated with a slight increase in turbidity (but remaining within acceptability criteria) and with SEC results, as HMWP increased in both 
cases (again remaining within acceptability criteria), and could therefore be in favour of mild aggregation. Alternatively, subvisible ice residues in the solutions after the thawing protocol cannot be excluded and may have caused the increased subvisible particle levels, however such a phenomenon wouldn't explain the alteration of the other parameters.

Aggregation phenomenon is well known for occurring after freeze-thawing stress of monoclonal antibodies [23]. $10 \mathrm{mg} / \mathrm{mL}$ solutions were reconstituted with water for injection only, thus their ionic strength was negligible. It has already been shown that an increase in salt concentration increases monoclonal antibodies Antigen-binding fragment [32], this results suggested that ionic strength could also prevent aggregation for infliximab solutions after freeze-thawing. The level of aggregation has been shown to be dependent of antibody concentration [23]. So the potential aggregation observed with $10 \mathrm{mg} / \mathrm{mL}$ infliximab solutions could be a combination of both ionic strength and concentration differences compared to the 0.4 and $2 \mathrm{mg} / \mathrm{mL}$ solutions, in a freezethawing stress situation.

An accidental freezing could happen during conservation, and yet the results of this study suggested a limited stability and no use after freezing should be accepted, especially for $10 \mathrm{mg} / \mathrm{mL}$ infliximab solutions. Further studies will allow determining the instability mechanism by performing harder stress conditions and increasing suspected instability signs.

The global impact of ambient temperature storage was observed for all conditions, as CEX and SEC chromatograms highlighted respectively a chemical and physical instability of infliximab molecules when samples were stored at $25^{\circ} \mathrm{C}$. However, differences in stability were also spotted between concentrated $(10 \mathrm{mg} / \mathrm{mL})$ and diluted solutions $(0.4$ and $2 \mathrm{mg} / \mathrm{mL})$ for the same temperature condition. Those differences could be explained by the sample concentration and the reconstitution solvent (for $10 \mathrm{mg} / \mathrm{mL}$ solutions the solvent was water for injection, whereas $\mathrm{NaCl} 0.9 \%$ was the main diluent for the $0.4 \mathrm{mg} / \mathrm{mL}$ and $2 \mathrm{mg} / \mathrm{mL}$ solutions). It has been shown that ionic strength has a stabilizing effect on the conformational and chemical stability of the fab fragment [33], and it can therefore be hypothesized that a possible way of increasing $10 \mathrm{mg} / \mathrm{mL}$ infliximab stability would be to prepare it with a saline solution and not with water for injection. The container itself (glass vials or polyolefin bags) may also play a role in infliximab solutions stability.

The assessment of physicochemical and structural properties is a good indicator to estimate mAbs stability, and we can suppose that infliximab binding to TNF will not be affected if physicochemical and structural properties are unchanged. Further biological effectiveness and immunogenicity studies will be needed to confirm that administration to patients is completely safe 
after long term storage. The reconstitution of infliximab solutions was performed under aseptic conditions, minimizing the risk of contamination but microbiological studies will be needed to extend long term storage recommendations. In clinical use conditions, stability of reconstituted and diluted infliximab solutions is set up to $24 \mathrm{~h}$ for both infliximab biosimilars (according to summary of product characteristics of both REMSIMA ${ }^{\circledR}[34]$ and INFLECTRA ${ }^{\circledR}[35]$ ), limited by a hypothetically short microbiological stability. Due to the high cost of infliximab, an extended stability is relevant for hospital pharmacies and particularly in centralized reconstitution units since infliximab solutions preparation could be optimized, and drug wastage reduced. Studies performed on another infliximab biosimilar (REMSIMA ${ }^{\circledR}$ ) have shown that infliximab diluted solutions were stable at least 7 days when diluted in $\mathrm{NaCl}$ bags $[29,36]$, but freshly reconstituted vials, and solutions in infusion bags diluted from an aged vials haven't been studied to our knowledge.

\section{Conclusion}

A complete characterization of an infliximab biosimilar physicochemical and structural properties was performed during this study. This stability study highlighted that chemical instability was the main stability limitation. The impact of storage temperature was confirmed, as infliximab solutions were more stable when stored at $5^{\circ} \mathrm{C}$ than at $25^{\circ} \mathrm{C}$; diluted solutions at 0.4 and $2 \mathrm{mg} / \mathrm{mL}$ were more stable than $10 \mathrm{mg} / \mathrm{mL}$ solutions. Both dilution and temperature had an impact on stability, but their respective roles remain to be precisely determined.

\section{Acknowledgments}

The authors thank Dr D. Bourdeaux for his technical and scientific help in starting this project, and for his thoughtful insights.

INFLECTRA $^{\circledR}$ vials were provided for free of charge by Pfizer France SAS. The studies were conducted as part of a 2016 research service contract between Pfizer and $\mathrm{CHU}$ Clermont-Ferrand for the evaluation of the physicochemical stability of infliximab (INFLECTRA $\left.{ }^{\circledR}\right)$ solutions.

\section{References}

[1] A. Beck, J.M. Reichert, Approval of the first biosimilar antibodies in Europe, MAbs. 5 (2013) 621-623. doi:10.4161/mabs.25864.

[2] Drugs@FDA: FDA Approved Drug Products, (n.d.). https://www.accessdata.fda.gov/scripts/cder/daf/index.cfm?event=overview.process\&AppINo=12554 4 (accessed May 4, 2017). 
[3] H.-C. Mahler, W. Friess, U. Grauschopf, S. Kiese, Protein aggregation: Pathways, induction factors and analysis, J. Pharm. Sci. 98 (2009) 2909-2934. doi:10.1002/jps.21566.

[4] W. Wang, Protein aggregation and its inhibition in biopharmaceutics, Int. J. Pharm. 289 (2005) 1-30. doi:10.1016/j.ijpharm.2004.11.014.

[5] A. Usami, A. Ohtsu, S. Takahama, T. Fujii, The effect of $\mathrm{pH}$, hydrogen peroxide and temperature on the stability of human monoclonal antibody, J. Pharm. Biomed. Anal. 14 (1996) 11331140. doi:10.1016/S0731-7085(96)01721-9.

[6] A. Lahlou, B. Blanchet, M. Carvalho, M. Paul, A. Astier, Mechanically-induced aggregation of the monoclonal antibody cetuximab, Ann. Pharm. Fr. 67 (2009) 340-352. doi:10.1016/j.pharma.2009.05.008.

[7] K.D. Ratanji, J.P. Derrick, R.J. Dearman, I. Kimber, Immunogenicity of therapeutic proteins: Influence of aggregation, J. Immunotoxicol. 11 (2014) 99-109. doi:10.3109/1547691X.2013.821564.

[8] C. Bardin, A. Astier, A. Vulto, G. Sewell, J. Vigneron, R. Trittler, M. Daouphars, M. Paul, M. Trojniak, F. Pinguet, Guidelines for the practical stability studies of anticancer drugs: A European consensus conference, Ann. Pharm. Fr. 69 (2011) 221-231. doi:10.1016/j.pharma.2011.07.002.

[9] International Conference of Harmonization (ICH), Quality Guidelines : ICH. Guidelines for stability Q1A to Q1f, (n.d.). http://www.ich.org/products/guidelines/\%20quality/article/qualityguidelines.html (accessed January 4, 2017).

[10] International Conference of Harmonization (ICH), Quality Guidelines : ICH. Guidelines Q6B: Specifications: Test procedures and Acceptance Criteria for Biotechnological.Biological Products., (n.d.). http://www.ich.org/products/guidelines/\%20quality/article/quality-guidelines.html (accessed January 4, 2017).

[11] $\quad \mathrm{CH}$ Q5C: quality of biotechnological products: Stability testing of biotechnological/biological products, (1995). http://www.ich.org/products/guidelines/quality/qualitysingle/article/stability-testing-of-biotechnologicalbiological-products.html (accessed April 4, 2017).

[12] A. Hawe, M. Wiggenhorn, M. van de Weert, J.H.O. Garbe, H. Mahler, W. Jiskoot, Forced degradation of therapeutic proteins, J. Pharm. Sci. 101 (2012) 895-913. doi:10.1002/jps.22812.

[13] D.S. Katayama, R. Nayar, D.K. Chou, J. Campos, J. Cooper, D.G. Vander Velde, L. Villarete, C. p. Liu, M. Cornell Manning, Solution behavior of a novel type 1 interferon, interferon- $\tau$, J. Pharm. Sci. 94 (2005) 2703-2715. doi:10.1002/jps.20461. 
[14] A. Hawe, J.C. Kasper, W. Friess, W. Jiskoot, Structural properties of monoclonal antibody aggregates induced by freeze-thawing and thermal stress, Eur. J. Pharm. Sci. 38 (2009) 7987. doi:10.1016/j.ejps.2009.06.001.

[15] 8th edition European Pharmacopeia, Particulate contamination : sub-visible particles, (2015).

[16] 8th edition European Pharmacopeia, Total protein, Method 2.5.33 (2008).

[17] European Pharmacopeia, 8.8, 2013.

[18] French Society of Clinical Pharmacy (SFPC), Evaluation and Research Group on Protection in Controlled Atmospher (GERPAC), Methodological guidelines for stability studies of pharmaceutical preparations, 2013. http://www.gerpac.eu/IMG/pdf/guide_stabilite_anglais.pdf.

[19] J. Vigneron, A. Astier, R. Trittler, J.D. Hecq, M. Daouphars, I. Larsson, B. Pourroy, F. Pinguet, SFPO and ESOP recommendations for the practical stability of anticancer drugs: An update, Ann. Pharm. Fr. 71 (2013) 376-389. doi:10.1016/j.pharma.2013.06.002.

[20] M. Santillo, S. Aiyalu, P. Austin, A Standard Protocol for Deriving and Assessment of Stability Part 2 - mAbstalk.com, (2015). http://mabstalk.com/a-standard-protocol-for-deriving-andassessment-of-stability-part-2/ (accessed March 21, 2017).

[21] K. Pisupati, A. Benet, Y. Tian, S. Okbazghi, J. Kang, M. Ford, S. Saveliev, K.I. Sen, E. Carlson, T.J. Tolbert, B.T. Ruotolo, S.P. Schwendeman, A. Schwendeman, Biosimilarity under stress: A forced degradation study of Remicade ${ }^{\circledR}$ and Remsima ${ }^{T M}$, MAbs. 0 (2017) 1-13. doi:10.1080/19420862.2017.1347741.

[22] E. Tamizi, A. Jouyban, Forced degradation studies of biopharmaceuticals: Selection of stress conditions, Eur. J. Pharm. Biopharm. 98 (2016) 26-46. doi:10.1016/j.ejpb.2015.10.016.

[23] L.A. Kueltzo, W. e. i. Wang, T.W. Randolph, J.F. Carpenter, Effects of Solution Conditions, Processing Parameters, and Container Materials on Aggregation of a Monoclonal Antibody during Freeze-Thawing, J. Pharm. Sci. 97 (2008) 1801-1812. doi:10.1002/jps.21110.

[24] E.Y. Chi, S. Krishnan, T.W. Randolph, J.F. Carpenter, Physical Stability of Proteins in Aqueous Solution: Mechanism and Driving Forces in Nonnative Protein Aggregation, Pharm. Res. 20 (2003) 1325-1336. doi:10.1023/A:1025771421906.

[25] J.C. Lin, Z.K. Glover, A. Sreedhara, Assessing the Utility of Circular Dichroism and FTIR Spectroscopy in Monoclonal-Antibody Comparability Studies, J. Pharm. Sci. 104 (2015) 4459-4466. doi:10.1002/jps.24683. 
[26] V. Vieillard, A. Astier, C. Sauzay, M. Paul, One-month stability study of a biosimilar of infliximab (Remsima ${ }^{\circledR}$ ) after dilution and storage at $4{ }^{\circ} \mathrm{C}$ and $25{ }^{\circ} \mathrm{C}$, Ann. Pharm. Fr. (2016). doi:10.1016/j.pharma.2016.08.002.

[27] S. Fekete, A. Beck, J.-L. Veuthey, D. Guillarme, Theory and practice of size exclusion chromatography for the analysis of protein aggregates, J. Pharm. Biomed. Anal. 101 (2014) 161-173. doi:10.1016/j.jpba.2014.04.011.

[28] S.K. Jung, K.H. Lee, J.W. Jeon, J.W. Lee, B.O. Kwon, Y.J. Kim, J.S. Bae, D.-I. Kim, S.Y. Lee, S.J. Chang, Physicochemical characterization of Remsima ${ }^{\circledR}$, MAbs. 6 (2014) 1163-1177. doi:10.4161/mabs.32221.

[29] V. Vieillard, A. Astier, C. Sauzay, M. Paul, One-month stability study of a biosimilar of infliximab (Remsima ${ }^{\oplus}$ ) after dilution and storage at $4{ }^{\circ} \mathrm{C}$ and $25{ }^{\circ} \mathrm{C}$, Ann. Pharm. Fr. (n.d.). doi:10.1016/j.pharma.2016.08.002.

[30] A. Sreedhara, Z.K. Glover, N. Piros, N. Xiao, A. Patel, B. Kabakoff, Stability of IgG1 monoclonal antibodies in intravenous infusion bags under clinical in-use conditions, J. Pharm. Sci. 101 (2012) 21-30. doi:10.1002/jps.22739.

[31] P. Qi, D.B. Volkin, H. Zhao, M.L. Nedved, R. Hughes, R. Bass, S.C. Yi, M.E. Panek, D. Wang, P. DalMonte, M.D. Bond, Characterization of the photodegradation of a human $\lg G 1$ monoclonal antibody formulated as a high-concentration liquid dosage form, J. Pharm. Sci. 98 (2009) 3117-3130. doi:10.1002/jps.21617.

[32] T. Wang, O.S. Kumru, L. Yi, Y.J. Wang, J. Zhang, J.H. Kim, S.B. Joshi, C.R. Middaugh, D.B. Volkin, Effect of ionic strength and pH on the physical and chemical stability of a monoclonal antibody antigen-binding fragment, J. Pharm. Sci. 102 (2013) 2520-2537. doi:10.1002/jps.23645.

[33] T. Wang, O.S. Kumru, L. Yi, Y.J. Wang, J. Zhang, J.H. Kim, S.B. Joshi, C.R. Middaugh, D.B. Volkin, Effect of ionic strength and $\mathrm{pH}$ on the physical and chemical stability of a monoclonal antibody antigen-binding fragment, J. Pharm. Sci. 102 (2013) 2520-2537. doi:10.1002/jps.23645.

[34] European Medicine Agency, Summary of products characteristics : REMSIMA, (2017).

[35] European Medicine Agency, Summary of products characteristics : INFLECTRA, (2017).

[36] B.L. Young, M.A. Khan, T.J. Chapman, R. Parry, M.A. Connolly, A.G. Watts, Evaluation of the physicochemical and functional stability of diluted REMSIMA ${ }^{\circledR}$ upon extended storage-A study compliant with NHS (UK) guidance, Int. J. Pharm. 496 (2015) 421-431. doi:10.1016/j.ijpharm.2015.10.016. 
